\title{
PENGARUH MODEL PEMBELAJARAN PROJECT BASED LEARNING TERHADAP HASIL BELAJAR DAN KEAKTIFAN BELAJAR SISWA DI SMK NEGERI 1 NGAWEN
}

\author{
Kiki Okta Dwi Utama \& Sukaswanto \\ Fakultas Teknik, Universitas Negeri Yogyakarta \\ Email: Kikiokta378@gmail.com
}

\begin{abstract}
This study aims (1) to determine the effect of using the Project Based Learning learning model on learning outcomes in Light Electricity Maintenance subjects at SMKN 1 Ngawen. (2) To determine the effect of the use of Project Based Learning learning methods on learning activeness in the subjects of Maintenance of Electric Vehicle Light in SMKN 1 Ngawen. This research is a quasi experiment with a pretest-posttest Control Group Design research design. The analysis test uses the independent sample T-test and descriptive analysis to describe the learning outcomes data and learning activeness. The results showed that: independent sample t-test on final learning outcomes or post-test obtained t count $>$ $t$ table is 2.964> 1,670. The significance value of the post-test results $0.004<0.05$, then Ho is rejected and $\mathrm{Ha}$ is accepted. This means that there is a significant difference between the results of the experimental class post-test with the control class. Then the results of the independent sample t-test on the students activeness obtained the results that t arithmetic $>t$ table is 5.543>1.670. Significance value t $0.00<0.05$, then Ho is rejected and Ha is accepted. This means that there is a significant difference in student activeness between the control class and the experimental class. Then it can be concluded that there is a significant influence on the project based learning model of learning outcomes learning and learning activeness of class XI students majoring in light vehicle engineering at State 1 Vocational School, Ngawen.
\end{abstract}

Keywords: Project Based Learning Models, Learning Outcomes, Student Activity.

\begin{abstract}
Abstrak
Penelitian ini bertujuan (1) Untuk mengetahui pengaruh penggunaan model pembelajaran Project Based Learning terhadap hasil belajar dalam mata pelajaran Pemeliharaan Kelistrikan Kendaraan Ringan di SMK N 1 Ngawen. (2) Untuk mengetahui pengaruh penggunaan model pembelajaran Project Based Learning terhadap keaktifan belajar dalam mata pelajaran Pemeliharaan Kelistrikan Kendaraan Ringan di SMK N 1 Ngawen. penelitian ini merupakan quasi eksperiment dengan desain penelitian pretest-posttest Control Group Design. Uji analisis menggunakan independent sample T-test dan analisis deskriptif untuk menggambarkan data hasil belajar dan keaktifan belajar. Hasil penelitian menunjukan bahwa: uji independent sample t-test pada hasil belajar akhir atau post-test diperoleh $\mathrm{t}$ hitung $>\mathrm{t}$ tabel yaitu 2,964 >1,670 . Nilai signifikansi hasil post-test $0.004<0,05$, maka Ho ditolak dan Ha diterima.hal ini berarti menyatakan bahwa terdapat perbedaan yang signifikan antara hasil posttest kelas eksperimen dengan kelas kontrol. Lalu hasil uji independent sample t-test pada keaktifan siswa diperoleh hasil bahwa t hitung $>\mathrm{t}$ tabel yaitu 5,543 > 1,670. Nilai signifikansi t $0.00<0,05$, maka Ho ditolak dan Ha diterima., Hal ini berarti menyatakan bahwa terdapat perbedaan yang signifikan keaktifan siswa antara kelas kontrol dan kelas eksperimen. Maka dapat disimpulkan terdapat pengaruh yang signifikan model pembelajaran project based learning terhadap hasil belajar dan keaktifan belajar siswa kelas XI jurusan teknik kendaraan ringan di SMK Negeri 1 Ngawen.
\end{abstract}

Kata Kunci: model project based learning, hasil belajar, keaktifan belajar siswa. 


\section{PENDAHULUAN}

Pendidikan dalam sudut pandang historis dimulai dari adanya kehidupan manusia dan terus berlangsung sepanjang hayat (long life education). Proses pendidikan yang banyak diajarkan di lembaga pendidikan guru adalah untuk mencapai proses kedewasaan siswa hingga mampu menetapkan suatu keputusan secara mandiri dan mempertanggungjawabkanya. Konsep ini secara operasional dalam pendidikan diterjemahkan sebagai pendidikan formal dengan langkah memberikan bekal pengetahuan kepada siswa untuk menghadapi masa depan.

Keberhasilan pendidikan formal tentunya sangat dipengaruhi oleh keberhasilan dalaam pelaksanaan belajar mengajar. Perihal yang lebih rinci dari suatu pelaksanaan kegiatan belajar mengajar sangat erat hubunganya dengan keterpaduan hubungan guru dengan kegiatan siswa. Kegiatan belajar mengajar ini sepenuhnya tidak lepas dari keseluruhan sistem pendidikan, untuk itu peningkatan kualitas kegiatan belajar mengajar dapat dilakukan dengan berbagai upaya oleh guru, seperti: penerapan pemahaman pada pola kegiatan belajar mengajar, cara mengajar, pengelolaan manajemen kelas, penerapan model pembelajaran yang tepat, hingga penilaian terhadap suatu proses belajar mengajar dan hasil belajar.

Salah satu cara dalam meningkatkan kualitas belajar dapat ditempuh dengan penerapan berbagai model pembelajaran yang tepat. Model tersebut selalu digunakan dalam setiap proses belajar mengajar. Pentingnya penerapan berbagai model pembelajaran sangat perlu diperhatikan karena siswa memiliki perbedaan dalam kemampuan, bakat, minat, ketahanan, dan semangat. Perbedaan gaya belajar juga merupakan faktor yang penting dalam proses belajar mengajar di kelas. Untuk itu diperlukan keragaman berbagai model mengajar untuk mencapai hasil belajar yang maksimal.

Pentingnya pendidikan bukan suatu hal yang diragukan lagi di seluruh dunia khususnya di Indonesia. Melalui pendidikan orang-orang lebih dapat mengoptimalkan bakat dan kemampuan yang mereka miliki. Mutu pendidikan akan mempengaruhi bagus atau tidakanya hasil yang diperoleh dari suatu pendidikan. Mutu pendidikan merupakan masalah yang dijadikan agenda utama untuk diatasi dalam kebijakan pembangunan pendidikan, karena hanya dengan pendidikan yang bermutu akan diperoleh lulusan bermutu yang mampu membangun diri, keluarga, masyarakat, bangsa dan negara. tidak terkecuali bagi Sekolah Menengah Kejuruan (SMK). SMK merupakan aset yang besar, apabila bangsa Indonesia ingin maju, pengangguran terkurangi, maka SMK perlu ditangani secara profesional. Meskipun SMK telah menunjukan peran-peran yang positif, namun kenyataannya saat ini masih dijumpai sejumlah permasalahan yang berdampak pada lulusannya, yaitu kualitas pembelajaran yang masih membutuhkan peningkatan, tantangan perubahan yang begitu cepat, serta kurang kolaborasi antara sekolah 
dengan Dunia Usaha dan Dunia Industri (DUDI). Beberapa permasalahan tersebut merupakan harapan yang sangat diidamkan untuk ditangani, sehingga tujuan SMK sebagai pendidikan yang menyiapkan tenaga profesional dapat terwujud.

SMK Negeri 1 Ngawen mempunyai visi Menjadi SMK yang Maju dan Bermutu serta Mencetak Lulusan Sesuai Harapan Stakeholders dan Mempunyai Kepedulian Terhadap Lingkungan. Demi mecapai visi tersebut sekolah secara berkelenjutan terus melakukan perbaikan dan peningkatan dari berbagai segi yang tertuang dalam misi yaitu dengan menyelenggarakan pembelajaran sistem Competency-Based Training (CBT) dan ProductionBased Education (PBE) menggunakan bilingual dengan pendekatan Information Communication Tehcnology (ICT), mengembangkan kurikulum, metodologi pembelajaran dan sistem penilaian berbasis kompetensi yang berkarakter, menyelenggarakan kegiatan ekstrakurikuler agar peserta didik mampu mengembangkan kecakapan hidup (life skill) dan berakhlak mulia meningkatkan kualitas tenaga pendidik dan kependidikan yang memenuhi kualifikasi profesional berkarakter budaya lokal meningkatkan fasilitas dan lingkungan belajar yang nyaman memenuhi standar kualitas dan kuantitas, menerapkan dan mengembangkan sistem manajemen mutu berbasis teknologi kekinian yang ramah lingkungan, ramah anak dan responsif gender dan membangun kemitraan dengan lembaga yang relevan baik dalam maupun luar negeri.

Peraturan Menteri Pendidikan dan Kebudayaan No. 3 Tahun 2007 dinyatakan bahwa dalam rangka meningkatkan mutu penilaian oleh pemerintah dan satuan pendidikan serta untuk mendorong pencapaian standar kompetensi lulusan secara nasional perlu menyelenggarakan Ujian Nasional (UN), ujian sekolah berstandar nasional dan ujian. Ujian Nasional dilakukan dengan harapan dapat diperoleh lulusan yang bermutu yang diakui di tingkat nasional, regional, maupun internasional. Demikian pula dengan pelaksanaan ujian nasional di tingkat sekolah menengah kejuruan.

Data dari https://puspendik.kemdikbud.go.id/hasil-un/ menyatakan bahwa nilai rata-rata UN di SMK N 1 Ngawen terus mengalami penurunan dari tahun 2015 sampai dengan tahun 2017. Pada tahun 2015 rata rata nilai UN 74.84, Pada tahun 2016 turun menjadi 67.54, dan pada tahun 2017 turun lagi menjadi 66.58. Pada tahun 2017 rata rata nilai UN berada pada peringkat 4 se Kabupaten Gunung Kidul. Dari data tersebut dapat disimpulkan bahwa prestasi belajar di SMK N 1 Ngawen terus mengalami penurunan.

Setelah dilakukan observasi di sekolah bersamaan dengan magang PLT 2018 juga didapatkan hasil yang kurang bagus pada hasil belajar peserta didik. Hasil pendalaman tengah semester mata pelajaran Pemeliharaan Kelistrikan Kendaraan Ringan kelas XI OA didapatkan hasil nilai tertinggi 82 dan nilai terendah 28, kelas XI OB didapatkan hasil nilai tertinggi 88 
dan nilai terendah 42, kelas XI OC didapatkan hasil nilai tertinggi 80 dan nilai terendah 34 dan untuk XI OD didapatkan hasil nilai tertinggi 78 dan nilai terendah 48, sedangkan nilai ketuntasan minimum di SMK N 1 Ngawen adalah 76 untuk setiap mata pelajaran. Dari hasil tersebut dapat diketahui bahwa hasil belajar peserta didik sebagian besar belum memenuhi terget yang ditentukan oleh sekolah. Hal itu di dapat dari hasil penelusuran dari jumlah siswa yang belum memenuhi standar Kriteria Kelulusan Minimum (KKM) yaitu hasil pendalaman tengah semester mata pelajaran Pemeliharaan Kelistrikan Kendaraan Ringan (PKKR) kelas XI OA didapatkan hasil nilai 19 siswa tidak mencapai batas minimal KKM, kelas XI OB didapatkan hasil nilai 15 siswa belum memenuhi standar minimal KKM, kelas XI OC didapatkan hasil nilai 18 siswa belum memenuhi batas minimal KKM dan nilai terendah 34 dan untuk XI OD didapatkan hasil nilai 21 siswa belum memenuhi batas minimal KKM, sedangkan nilai ketuntasan minimum di SMK N 1 Ngawen adalah 76 untuk setiap mata pelajaran.

Permasalahan lain yang terjadi adalah penerapan model-model pembelajaran yang belum baik. Dalam kenyataannya guru masih mengajar dengan metode konvensional meskipun Rencana Pelaksanaan Pembelajaran (RPP) yang dibuat sudah mengacau pada kurikulum 2013. Kurikulum 2013 menuntut guru untuk mengetahui metode pembelajaran Scientific yaitu pembelajaran berpusat pada siswa bukan berpusat pada guru lagi. Metode pembelajaran Scientific mengajar siswa untuk belajar secara aktif, sehingga pembelajaran tidak lagi terpusat pada guru. Karena penerapan metode Scientific masih rendah maka masalah-masalah yang terjadi di dalam proses pembelajaran adalah peserta didik menjadi cepat bosan dan tidak tertarik terhadap materi pelajaran. Dalam metode yang diterapkan oleh guru ini tidak terjadi proses interaksi dua arah antara garu dengan peserta didik. Peserta didik cenderung pasif saat pembelajaran karena guru mendominasi untuk mengajarkan materi kepada peserta didik, selain itu murid juga cenderung pasif pada saat pelajaran di kelas. Permasalahan permasalahan ini pasti akan sangat mempengaruhi hasil belajar peserta didik nanti karena keberhasilan dalam pembelajaran dapat diwujudkan diantaranya yaitu dengan menerapkan pembelajaran dengan efektif dan efisien.

Untuk menemukan metode pembelajaran diperlukan beberapa pertimbangan supaya proses pembelajaran menjadi efektif dan efisien. Hal yang perlu dipertimbangkan dalam memilih suatu metode pembelajaran yaitu diantaranya adalah karakter materi pelajaran, ketersediaan sarana belajar, kemampuan dasar siswa, dan alokasi waktu pembelajaran. Hai ini dimaksudkan pembelajaran tidak hanya sekedar bertujuan agar peserta didik memiliki pengetahuan dan ketrampilan saja, namun juga diharapkan memiliki sikap yang memadai untuk memecahkan masalah dalam dunia kerja dan kehidupan sehari-hari. 
Berlatar permasalahan permasalahan tersebut peneliti berupaya menemukan penyelesaian permasalahan tentang keaktifan dan hasil belajar di sekolah tersebut yang dirasa bisa diselesaikan dengan model pembelajaran yang akan peneliti uji. Oleh karena itu dibutuhkan model pembelajaran yang dapat meningkatkan keaktifan siswa agar hasil belajar siswa dapat meningkat, misalkan saja Problem based learning (Nurtanto \& Sofyan, 2015; Tafakur \& Suyanto, 2015). Model pembelajaran yang akan digunakan peneliti sebagai bahan eksperimen untuk melihat perbedaan pengaruh keaktifan dan hasil belajar adalah Metode pembelajaran Project Based Learning (PjBL ) yang akan diaplikasikan pada mata pelajaran Pemeliharaan Kelistrikan Kendaraan Ringan di kelas XI jurusan teknik kendaraan ringan . Model pembelajaran ini di angkat dari suatu masalah yang mungkin dialami oleh peserta didik dan selanjutnya akan dibahas dari berbagai sisi yang relevan sehingga diperolah pemecahan secara menyeluruh, bermakna, dan relevan dengan kenyataan yang ada.

Dari sebab itu peneliti akan melakukan penelitian tentang pengaruh model Pembelajaran berbasis proyek dengan hasil dan keaktifan belajar siswa yang akan di bandingkan dengan model pembelajaran konvensional.

\section{METODE}

Jenis penelitian yang digunakan pada penelitian ini adalah penelitian eksperimental. Sugiyono (2006:107) mengemukakan penelitian eksperimen dapat diartikan sebagai metode penelitian yang digunakan untuk mencari pengaruh perlakuan tertentu terhadap yang lain dalam kondisi terkendalikan. Penelitian ini menggunakan pendekatan kuantitatif. Penelitian ini dilakukan di Sekolah Menengah Kejuruan pada program keahlian teknik kendaraan ringan yang ada di SMK Negeri 1 Ngawen. Pelaksanaan waktu penelitian pada tahun ajaran 2019/2020 pada bulan Juli-Agustus 2019.

Menurut sugiyono (2010:117) populasi adalah wilayah generalisasi yang terdiri atas obyek/ yang mempunyai kualitas dan karakteristik tertentu yang ditetabkan olehy peneliti untuk dipelajari dan kemudian ditarik kesimpulanya. Sedangkan sampel sugiyono (2010:118) juga menjelaskan sampel adalah bagian dari jumlah karakteristik dari populasi.selain itu untuk teknik sampling Margono (2004) menjelaskan teknik sampling merupakan cara untuk menentukan sampel yang jumlahnya sesuai dengan ukuran sampel yang akan digunakansumber data sebenarnya dengan memperhatikan karakteristik agar memperoleh sampel yang representatif. Populasi penelitian ini adalah seluruh siswa kelas XI jurusan Teknik Kendaraan Ringan SMK N 1 Ngawen, yaitu kelas XI OA, XI OB, XI OC, XI OD. Teknik sampling yang digunakan adalah teknik simple random sampling atau penarikan kelompok satu tahap secara 
mudah dan acak. Untuk menggunakan teknik sampling ini sifat karakteristik kelompok harus homogen. oleh karena itu peneliti menguji hasil pendalaman mid semester siswa. Setelah itu dilakukan teknik simple random sampling dengan cara membuat undian dari nama populasi tersebut dan di ambil secara random. Maka di dapat hasil keputusan yaitu kelas XI OB sebagai kelas eksperimen yang berjumlah 31 siswa dan kelas XI OC sebagai kelas kontrol yang berjumlah 31 siswa.

Metode pengumpulan data pada penelitian ini menggunakan observasi, test hasil belajar siswa, dan dokumentasi. Test yang akan digunakan pada penelitian ini adalah test pilihan ganda. Tes dilakukan sebelum dan sesudah kelas eksperimen maupun kelas kontrol dikenai perlakuan. Sebelum tes diberikan, terlebih dahulu soal yang akan digunakan untuk tes di uji cobakan guna mengetahui validitas, reliabilitas, daya beda dan tingkat kesukaran.

Instrumen penelitian yang dipergunakan untuk pengambilan data berupa Lembar keterlaksanaan pembelajaran, Lembar Pengamatan Keaktifan Siswa, dan Test hasil belajar. Nunnally, (1978) yang dikutip Badrun Kartowagiran dalam buku penilaian pembelajaran kejuruan mengemukakan validitas suatu alat ukur adalah sejauhmana alat ukur itu mampu mengukur apa yang seharusnya diukur. Sementara itu, Linn dan Gronlund (1995) yang dikutip Badrun Kartowagiran dalam buku penilaian pembelajaran kejuruan menjelaskan validitas mengacu pada kecukupan dan kelayakan interprestasi yang dibuat dari penilaian, berkenaan dengan penggunaan khusus.

Instrumen yang digunakan untuk pengumpulan data terlebih dahulu dikonsultasikan kepada pakar untuk melihat apakah instrumen itu valid atau tidak. Pengujian validasi dalam penelitian ini dilakukan melalui pertimbangan dari ahli (expert judgement). Hal ini dilakukan untuk mengevaluasi dan memeriksa secara sistematis terhadap instrument yang akan digunakan, sehingga instrument dikatakan valid dan layak dipergunakan untuk melaksanakan pengumpulan data / penelitian.

Menurut Ardhana12 (dalam Lexy J. Moleong 2002: 103) menjelaskan bahwa analisis data adalah proses mengatur urutan data, mengorganisasikanya ke dalam suatu pola, kategori, dan satuan uraian dasar. Menurut Taylor, (1975: 79) mendefinisikan analisis data sebagai proses yang merinci usaha secara formal untuk menemukan tema dan merumuskan hipotesis (ide) seperti yang disarankan dan sebagai usaha untuk memberikan bantuan dan tema pada hipotesis.

Pengujian hipotesis yang digunakan dalam penelitian ini adalah Uji-t. Uji-t merupakan salah satu uji hipotesis statistik parametris yang digunakan untuk komparatif rata-rata dua sampel bila datanya berbentuk interval atau rasio. Uji-t ini dilakukan untuk mengetahui adanya pengaruh atau tidak antara hasil belajar dan keaktifan kelompok eksperimen dan kelompok 
kontrol. Uji-t dalam penelitian ini dilakukan sebanyak empat kali. Dua kali untuk menguji hasil belajar dan dua kali untuk menguji keaktifan siswa.

\section{HASIL DAN PEMBAHASAN}

\section{Deskripsi Data Penelitian}

Data penelitian keaktifan siswa diperoleh dari hasil observasi lembar keaktifan siswa selama dua kali pertemuan dan hasil belajar diperoleh dari pre-test dan post-test pada kelompok eksperimen dan kelompok kontrol. Pre-test dilakukan sebelum diberikan perlakuan dengan tujuan untuk mengetahui kemampuan prestasi belajar awal. Setelah dilakukan perlakuan maka diadakan post-test untuk mengetahui prestasi belajar akhir siswa setelah di kenakan perlakuan. Berikut akan disajikan deskripsi data test hasil belajar dan keaktifan siswa yang telah diperoleh melalui pembelajaran selama dua kali pertemuan setiap kelompoknya, baik kelompok ekperimen dan kelompok kontrol. Selanjutnya data hasil penelitian dlakukan analisis deskriptif dengan hasil sebagai berikut :

\section{1) Data hasil belajar pre-test}

Pada kelas kontrol diperoleh data nilai tertinggi yaitu 66.00 dan nilai terendah adalah 33.00. Didapat nilai mean sebesar 46.96, nilai median sebesar 46, nilai mode sebesar 53 dan nilai standar deviation sebesar 9.097.

Pada kelas eksperimen diperoleh data nilai tertinggi yaitu 60.00 dan nilai terendah adalah 33.00. Didapat nilai mean sebesar 46.45, nilai median sebesar 43, nilai mode sebesar 53 dan nilai standar deviation sebesar 9.021

\section{2) Data hasil belajar post-test}

Pada kelas kontrol diperoleh data nilai tertinggi yaitu 83.00 dan nilai terendah adalah 66.00. Didapat nilai mean sebesar 77.451, nilai median sebesar 76.00, nilai mode sebesar 76.00 dan nilai standar deviation sebesar 4.321.

Pada kelas eksperimen diperoleh data nilai tertinggi yaitu 90.00 dan nilai terendah adalah 76.00. Didapat nilai mean sebesar 80.709, nilai median sebesar 80.00, nilai mode sebesar 76.00 dan nilai standar deviation sebesar 4.321

\section{3) Data keaktifan belajar kelas eksperimen}

Data keaktifan siswa diambil selama dua pertemuan dengan isntrumen berapa penilaian keaktifan belajar yang terdiri dari 10 poin penilaian observasi dan setiap poin yang dilakukan nilainya 1 dan 0 poin jika tidak dilaksanakan oleh siswa . hasilnya sebagai berikut : 
86 Kiki Okta Dwi Utama, Sukaswanto, Lilik Chaerul Yuswono

Pertemuan pertama diperoleh nilai keaktifan tertinggi sebesar 10,00, Nilai terendah sebesar 6,00, Nilai mean sebesar 7,903, nilai median sebesar 8,00 nilai modus sebesar 7,00 dan nilai standar deviasi sebesar 1,3001 .

Pertemuan kedua diperoleh nilai keaktifan tertinggi sebesar 10,00 Nilai terendah sebesar 7,00 , nilai mean sebesar 8,45 , nilai median sebesar 8,00 nilai modus sebesar 7,00 dan nilai standar deviasi sebesar 1,120.

\section{4) Data keaktifan belajar kelas kontrol}

Pertemuan pertama diperoleh nilai keaktifan tertinggi sebesar 8,00, Nilai terendah sebesar 5,00 , Nilai mean sebesar 6,225, nilai median sebesar 6,00, nilai modus sebesar 6,00 dan nilai standar deviasi sebesar 1,023

Pertemuan kedua diperoleh nilai keaktifan tertinggi sebesar 8,00 Nilai terendah sebesar 5,00 , nilai mean sebesar 6,967 , nilai median sebesar 7,00 nilai modus sebesar 7,00 dan nilai standar deviasi sebesar 0,982 .

\section{Uji prasyarat Analisis}

\section{Uji normalitas}

Kriteria pengujian yaitu jika nilai signifikansi lebih dari 0,05 maka data berdistribusi normal Pada hasil belajar Uji normalitas dilakukan dua kali yaitu pada nilai pretest dan posttest kelas kontrol dan eksperimen. dan hasilnya adalah didapat nilai signifikan pada kelas eksperimen 0,798 dan 0, 149. Pada kelas kontrol adalah 0,734 dan 0,291. Dari data tersebut dapat diketahui nilai signifikan lebih dari 0,05, maka dapat dinyatakan data berdistribusi normal.

Pada data keaktifan siswa Uji normalitas dilakukan pada data keaktifan siswa baik pada pertemuan pertama dan kedua pada kelas kontrol dan kelas eksperimen dan hasilnya adalah nilai hasil uji normalitas pada kelas eksperimen 0,137 dan 0,314. Pada kelas kontrol adalah 0,166 dan 0,092. Dari data tersebut dapat diketahui nilai signifikan lebih dari 0,05, maka dapat dinyatakan data keaktifan siswa berdistribusi normal.

\section{Uji homogenitas}

Kriteria pengujian yaitu jika nilai signifikansi lebih dari 0,05 dan Fhitung kurang dari $\mathrm{F}$ tabel maka data bersifat homogen.

\section{a) Uji homogenitas hasil belajar}

Hasil pada nilai pretest adalah Fhitung adalah 0,145 dengan nilai signifikan yaitu 0,705 . nilai Fhitung kurang dari Ftabel yaitu 0,145<4,66 dan nilai sig. Lebih dari 0,05 yaitu 0,705>0,05. Maka dapat disimpulkan data hasil pretest kelas kontrol dengan kelas eksperimen bersifat homogen. 
Hasil pada nilai post-test adalah F hitung : 0,001 dengan nilai sig : 0.995. Nilai Fhitung < Ftabel yaitu $0,001<4,66$ dan sig $>0,05$ yaitu $0,995>0,05$, maka dapat disimpulkan data tersebut bersifat homogen.

\section{b) Uji homogenitas keaktifan belajar}

Pada pertemuan pertama di dapat $\mathrm{F}$ hitung adalah 1,847 dengan nilai sig 0,179 . Nilai Fhitung < Ftabel yaitu 1,847< 4,66 dan sig > 0,05 yaitu 0,179>0,05, maka dapat disimpulkan data tersebut bersifat homogen

Pada pertemuan kedua di dapat $F$ hitung adalah 2,847 dengan nilai sig 0,118. Nilai Fhitung $<$ Ftabel yaitu 2,847 < 4,66 dan sig > 0,05 yaitu 0,118>0,05, maka dapat disimpulkan data tersebut bersifat homogen.

\section{Uji hipotesis}

Kriteria pengujian dengan independent sampel T-test adalah Apabila nilai $t$ hitung $\geq$ dari $t$ tabel dan $\mathrm{P} \leq 0,05$ maka Ha diterima dan Ho ditolak bagitu juga sebaliknya.

\section{1) Uji T pre-test}

Hipotesisnya adalah :

Ho : tidak terdapat perbedaan yang signifikan antara hasil pre-test kelas kontrol dan kelas eksperimen.

Ha : terdapat perbedaan yang signifikan antara hasil pre-test kelas kontrol dan kelas eksperimen.

Di dapat hasil t hitung $<$ ttabel yaitu $0,224<1,999$. Nilai signifikansi hasil pre-test 0.823 $>0,05$, maka Ho diterima dan Ha ditolak.

\section{2) Uji T post-test}

Ho : tidak terdapat perbedaan yang signifikan antara hasil post-test kelas kontrol dan kelas eksperimen.

Ha : terdapat perbedaan yang signifikan antara hasil post-test kelas kontrol dan kelas eksperimen.

Di dapat hasil $\mathrm{t}$ hitung $>\mathrm{t}$ tabel yaitu 2,964 > 1,999. Nilai signifikansi didapat lebih kecil dari 0,05 yaitu $0.004<0,05$, maka Ho ditolak dan Ha diterima

\section{3) Uji T keaktifan siswa}

Ho : tidak terdapat perbedaan yang signifikan antara keaktifan siswa kelas kontrol dan kelas eksperimen.

Ha : terdapat perbedaan yang signifikan antara keaktifan siswa kelas kontrol dan kelas eksperimen.

Didapat hasil $\mathrm{t}$ hitung $>\mathrm{t}$ tabel yaitu 5,543 $>1,999$. Nilai signifikansi keaktifan belajar yaitu $0.00<0,05$, maka Ho ditolak dan Ha diterima 


\section{PEMBAHASAN}

\section{Pengaruh model pembelajaran PjBL terhadap hasil belajar}

Hasil penelitian menunjukkan bahwa pencapaian kompetensi pada kelas eksperimen ratarata hasil pre-test yang diperoleh sebesar 46,45 dengan nilai tertinggi sebesar 60 dan nilai terendah sebesar 33. Sedangkan rata-rata hasil pre-test kelas kontrol sebesar 46.96 dengan nilai tertinggi sebesar 66 dan nilai terendah sebesar 33. Untuk rata-rata hasil post-test pada kelas eksperimen sebesar 80.709 dengan nilai tertinggi sebesar 90 dan nilai terendah sebesar 76 dan rata-rata hasil post-test pada kelas kontrol sebesar 77.451 dengan nilai tertinggi sebesar 83 dan nilai terendah sebesar 66. Untuk kelas eksperimen memiliki jumlah siswa 31 dan kelas kontrol juga memiliki jumlah siswa 31.

Jika dilihat dari batas kriteria ketuntasan minimal (KKM) yaitu 76 untuk semua mata pelajaran maka Hasil belajar yang diperoleh siswa saat dilakukan pre-test baik kelas eksperimen maupun kelas kontrol belum ada siswa yang mencapai KKM, Sedangkan setelah dilakukan post-test, pada kelas eksperimen semua siswa sudah mencapai KKM, sedangkan kelas kontrol terdapat 5 siswa yang belum mencapai KKM.

Pengaruh model pembelajaran Project Based Learning terhadap hasil belajar pada mata pelajaran PKKR diketahui dengan membandingkan hasil belajar pre-test kelas kontrol dan kelas eksperimen serta nilai post-test kelas kontrol dan kelas eksperimen menggunakan pengujian hipotesis t-test dengan taraf signifikan 5\%. Berdasarkan hasil tabel uji t-test pada pre-test kelas kontrol dan kelas eksperimen diketahui bahwa t hitung $<$ ttabel yaitu 0,224 $<1,670$, dan Nilai signifikansi $0.823>0,05$, sehingga dapat disimpulkan bahwa tidak terdapat perbedaan yang signifikan hasil pre-test kelas kontrol dan pre-test kelas eksperimen. hal itu karena kemampuan siswa baik kelas eksperimen maupun kelas kontrol bersifat sama/homogen sebelum di treatment. Hasil tabel uji t-test pada post-test kelas kontrol dan kelas eksperimen diperoleh t hitung > t tabel yaitu 2,964 > 1,670 dan Nilai signifikansi lebih kecil dari 0,05 yaitu $0.04<$ 0,05, maka dapat disimpulkan terdapat pengaruh yang signifikan penerapan model pembelajaran Project Based Learning pada mata pelajaran PKKR terhadap hasil belajar siswa kelas XI SMK N 1 Ngawen.

Pengaruh penerapan model pembelajaran Project Based Learning terhadap hasil belajar siswa dilihat berdasarkan hasil nilai pre-test dan post-test. Pengaruh terhadap hasil tersebut diperoleh karena subyek penelitian bersifat homogen, kemampuan siswa yang dijadikan subjek penelitian merata pada semua kelas, pengaruh masing-masing model pembelajaran yang diberikan baik pada kelas kontrol maupun kelas eksperimen setelah dilakukan pre-test kepada siswa sehingga dapat diketahui kemampuan akhir siswa dalam proses pembelajaran. Dan jika 
dilihat pada rata-rata hasil belajar Post-test antara kelas eksperimen dan kelas kontrol, yaitu didapat rata-rata nilai post-test kelas kontrol adalah 80,70 dan rata-rata nilai post-test pada kelas eksperimen adalah 77,65. Maka dapat di simpulkan bahwa terdapat pengaruh penggunaan model pembelajaran Project Based Learning terhadap hasil belajar siswa mata pelajaran pemeliharaan kelistrikan kendaraan ringan di SMK Negeri 1 Ngawen.

\section{Pengaruh model pembelajaran PjBL terhadap keaktifan belajar}

Keaktifan siswa baik di kelas eksperimen dan kelas kontrol diamati menggunakan lembar observasi. Pembelajaran dilakukan dua kali tatap muka untuk setiap kelas. Proses pembelajaran pertama yang dilakukan pada kelas eksperimen yaitu menerapkan model pembelajaran Project Based Learning yang terdiri dari langkah pembelajaran yaitu: pendahuluan, kegiatan inti, dan penutup. Selama proses pembelajaran siswa dibagi menjadi 6 kelompok yang terdiri dari 5-6 siswa. Pada pertemuan kedua siswa mulai terbiasa dalam proses pembelajaran Project based Learning. Siswa diberikan kebebasan dalam proses pembelajaran. Siswa yang awalnya pasif menjadi aktif. Siswa mulai bertanya hal-hal yang mereka tidak mengetahuinya mengenai materi pembelajaran, dan mulai mengeluarkan ide-ide nya tanpa takut akan salah atas pendapatnya Berdasarkan proses pembelajaran yang telah dilakukan terlihat bahwa siswa lebih banyak mendapatkan informasi sesuai usaha mereka masing-masing dan lebih banyak pertanyaan yang muncul sehingga proses pembelajaran lebih kondusif. Setiap anggota kelompok mempunyai tugas masing-masing dan juga membantu anggota kelompok yang kurang paham dengan materi yang diberikan.

Dalam kelas kontrol menggunakan model pembelajaran konvensional dengan metode ceramah kurang aktif dalam bertanya dan menjawab pertanyaan. Hal tersebut terjadi karena pada kelas kontrol yang diterapkan model pembelajaran tersebut, siswa cenderung lebih pasif dan membosankan karena siswa menjadi monoton. Hanya guru yang lebih berperan dalam menjelaskan materi dan siswa cenderung hanya menerima dan saat diadakan sesi tanya jawab hanya sedikit siswa yang bertanya karena sejumlah besar siswa tidak mengeksplore pelajaran dari guru dan hanya cenderung mendengarkan apa yang disampaikan saja tanpa berpikir kreatif tentang apa informasi yang bisa digali dari materi pelajaran yang diajarkan. Keterlibatan siswa belajar dengan cara mendengarkan guru tidak akan membuat siswa menjadi aktif dalam proses pembelajaran.

Dalam kelas eksperimen lebih aktif dibandingkan kelas kontrol. Hal ini disebabkan pembelajaran Project based Learning yang diterapkan di kelas eksperimen. Mendorong siswa untuk aktif dalam proses pembelajaran. Siswa dibentuk dalam beberapa kelompok agar dapat mengkomunikasikan sesama teman berkaitan ide-ide yang dibahas saat belajar. Siswa didorong untuk mampu menyelesaikan persoalan rancangan proyek yang diberikan secara berkelompok 
90 Kiki Okta Dwi Utama, Sukaswanto, Lilik Chaerul Yuswono

dan siswa didorong untuk lebih aktif mengeksplore sumber informasi dari mana saja asalkan valid. Selain itu siswa juga dituntut untuk berpikir sekreatif mungkin karena proyek yang di beri ke setiap kelompok tidak ada patokan atau batasan desain, detail jawaban, dan berbagai kreatifitas lainya.

Dari data yang didapat yaitu rata-rata nilai cek list lembar observasi nilai akhir yaitu di observasi ke-2 di kelas kontrol adalah 6,967 dan pada kelas eksperimen adalah 8,451. Dan diketahui bahwa hasil uji independent $t$-test di dapat $t$ hitung $>\mathrm{t}$ tabel yaitu 5,543 > 1,670 . Nilai signifikansi yaitu $0.00<0,05$, maka Ho ditolak dan Ha diterima. Hal ini berarti menerima hipotesis kedua yang menyatakan bahwa terdapat perbedaan keaktifan siswa yang signifikan antara kelas kontrol dan kelas eksperimen dan menolak hipotesis pertama yang menyatakan tidak terdapat perbedaan yang signifikan antara keaktifan siswa kelas kontrol dan kelas eksperimen. maka dapat disimpulkan bahwa terdapat pengaruh penggunaan model pembelajaran Project Based Learning terhadap keaktifan belajar siswa mata pelajaran pemeliharaan kelistrikan kendaraan ringan di SMK Negeri 1 Ngawen.

\section{SIMPULAN DAN SARAN}

Berdasarkan hasil penelitian dan pembahasan, maka dapat disimpulkan bahwa terdapat pengaruh yang signifikan penggunaan model pembelajaran Project Based Learning terhadap hasil belajar dan keaktifan mata pelajaran pemeliharaan kelistrikan kendaraan ringan kelas XI di SMKN 1 Ngawen.

Dengan penerapan model pembelajaran yang menumbuhkan keaktifan dan semangat belajar siswa seperti moel pembelajaran project based learning ini diharapkan siswa dapat lebih semangat dalam proses pembelajaran di kelas dan mencapai hasil belajar yang maksimal.

\section{DAFTAR PUSTAKA}

Amirono dan Daryanto. (2016). Evaluasi dan Penilaian Pembelajaran Kurikulum 2013. Yogyakarta: Grava Media.

Badrun K. (2016). Modul Penilaian Pembelajaran Kejuruan. Yogyakarta: UNY

Baharuddin Esanu Nur Wahyuni. (2016). Teori Belajar \& Pembelajaran. Yogyakarta: Ar-Ruzz Media Group.

Daryanto dan Rahardjo, M. (2012). Model Pembelajaran Inovatif. Yogyakarta: Gava Media.

Data nilai siswa di akses dari : https://puspendik.kemdikbud.go.id/hasil-un/

Dimyati \& Mujiono. (2009). Belajar dan Pembelajaran. Jakarta: Rineka Cipta. 
Harnila. (2016). Pengaruh Model Project Based LearningTerhadap Hasil Belajar Siswa Kelas X Sman 1 Unggul Seulimum Aceh Besar Pada Materi Minyak Bumi . Diambil dari http://jurnaltarbiyah.uinsu.ac.id/tarbiyah/article.html

Hassamah (2018). Belajar dan Pembelajaran. Malang: Universitas Muhamadiyah Malang.

Khanifatul (2013). Pembelajaran Inovatif : Strategi Mengelola Kelas Secara Efektif Dan Menyenangkan. Yogyakarta: Ar-Ruzz Media Group.

Kusaeri. (2016). Acuan \& Teknik Penilaian Proses \& Hasil Belajar dalam Kurikulum 2013. Yogyakarta: Ar-Ruzz Media Group.

Marno \& Idris (2014). Strategi, Metode, Dan Teknik Mengajar (Menciptakan Keterampilan Mengajar Secara Efektif Dan Edukatif). Yogyakarta: Ar-Ruzz Media Group.

Mulyasa, E. (2014). Implementasi Kurikulum 2013. Bandung: PT Remaja Rosdakarya.

Nayono, Satoto E. (2013) Pengembangan Model Pembelajaran Project Based Learning Pada Mata.

Noto, Widodo (2012) Pengaruh Penggunaan Diagnosis Chart Terhadap Hasil Belajar Matakuliah prakti Diagnosis Sistem Kelistrikan, Jurnal Pendidikan Teknik Kejuruan : UNY.

Nurtanto, M., \& Sofyan, H. (2015). Implementasi problem-based learning untuk meningkatkan hasil belajar kognitif, psikomotor, dan afektif siswa di SMK. Jurnal Pendidikan Vokasi, 5(3), 352-364.

Prabowo, Candra Tri. (2015). Pengaruh Metode Pembelajaran Project Based Learning Terhadap Prestasi Belajar Siswa Mata Pelajaran Las Lanjut Kelas XI Jurusan Teknik Permesinan SMK Muhammadiyah Prambanan. Diambil dari: http://eprints.uny.ac.id/26335/1/Candra\%20TP10503244034.pdf

Sugiharto DKK. (2015). Psikologi Pendidikan. Yogyakarta: UNY press.

Sugiyono. (2006) Metode Penelitian Pendidikan. Bandung: Alfabeta.

Tafakur, T., \& Suyanto, W. (2015). Pengaruh cooperative project-based learning terhadap motivasi dan hasil belajar praktik "perbaikan motor otomotif" di SMKN 1 Seyegan. Jurnal Pendidikan Vokasi, 5(1), 117-131. 
92 Kiki Okta Dwi Utama, Sukaswanto, Lilik Chaerul Yuswono 